\title{
Civilization and Savagery in the Crucible of $\mathrm{War}^{1}$
}

\section{BRETT BOWDEN*}

\author{
(Australian National University)
}

The casting of the war on terrorism as a war fought on behalf of or for Civilization against some less-than-civilized Other-terrorists and their cohorts-is a significant point. The image being generated and marketed is one of a war between the civilized defenders of everything that Civilization represents and the savage terrorists who oppose it and want to tear it down. Right or wrong, this image is not exactly new, and thus the 'war on terror' is not exactly a 'war like no other' as is often claimed by its prosecutors. Rather, history and precedents, particularly in regard to confrontations between so-called 'civilized' and 'savage' peoples, have a lot to tell us about the present and the conducting of the war on terror.

The world is at war: an open-ended 'war on terrorism'. Leaders across the world have repeated the declaration ad nauseam. We have been told just as many times that it is a 'war like no other'. The stakes are high. If Osama bin Laden is to be believed it is the 'Third World War'; for George W. Bush the war is nothing less than a 'fight for civilization'. Both sides are convinced it is a definitive battle between the forces of 'good' and the powers of 'evil', and that they are the righteous with God on their side. Echoing the Bush administration's declarations about a pernicious 'axis of evil' and claims that 'either you are with us, or you are with the terrorists', ${ }^{2}$ Ayman al-Zawhiri, al-Qa'ida's second in command, has similarly outlined a 'dichotomous struggle for God's sovereignty on earth [which] eliminates the middle ground and sets the stage for a millennial, eschatological battle between good and evil'. 3

As to whether the terrorist attacks on the United States on September 11, 2001 were in fact an act of war demanding a military response or a criminal act demanding a legal and justice-based response is open to question and debate. Secretary of State Colin Powell's initial response suggests that he regarded it more in terms of a crime than an act of war: 'you can be sure that America will deal with this tragedy in a way that brings those responsible to justice', he is reputed to have said. But President Bush had other ideas, later telling Bob Woodward that his immediate reaction was: 'They had declared war on us, and I made up my mind at that moment that we were going to war. ${ }^{4}$ And thus we are at war.

* Brett Bowden, Centre for International Governance \& Justice, Regulatory Institutions Network, Australian National University, Canberra, ACT 0200, Australia. Tel: +61-7-61255-1502; Fax: +61-7-6125-1507; Email: $<$ Brett.Bowden@anu.edu.au>

1 I am most grateful to Gerda Roelvink and two anonymous reviewers for their thoughtful comments on this essay.

2 George W. Bush, Address to a Joint Session of Congress and the American People, 20 September 2001, <http:// www.whitehouse.gov/news/releases/2001/09/20010920-8.html> (accessed 12 September 2006).

3 Quintan Wiktorowicz, 'A Genealogy of Radical Islam', Studies in Conflict \& Terrorism, 28, 2 (2005), p. 81. Wiktorowicz includes extracts from al-Zawhiri's pamphlet, Knight's under the Prophet's Banner.

4 John Denvir, 'Bush's Savage War', Picturing Justice, 9 January 2004 <www.usfca.edu/pj/savage_denvir.htm> (accessed 12 September 2006). See also Bob Woodward, Plan of Attack (New York: Simon \& Schuster, 2004). 
The casting of the war on terrorism as a war fought on behalf of or for Civilization against some less-than-civilized Other-terrorists and their cohorts-is a significant point that cannot be allowed to pass unexamined. The image being generated and marketed here is one of a war between the civilized defenders of everything that Civilization represents and the barbarous terrorists who oppose it and want to tear it down. (A similar argument, ironically enough, is posited by bin Laden and others on the other side of this Manichean divide.) Right or wrong, this image is not exactly new, and thus the 'war on terror' is not exactly a war like no other. Rather, history and precedents have a lot to tell us about the present and the conducting of this war on terror.

Throughout much of organized human history the peoples, societies and states of our world have been hierarchically divided on the basis of their approximation to the ideal of civilization (the self-proclaimed most civilized doing the dividing). The most advanced collectives of peoples, civilized states, sit at the apex of civilizational hierarchy; those at the polar opposite are said to be not far removed from the state of nature. Somewhere in between these two poles at various stages of human and social development are barbarians and even less developed savage peoples. Along with a capacity for socio-political organization and self-government, means of warfare employed in the crucible of war have long been regarded as key markers of civilization-or the absence thereof. As Gerrit Gong explains in his account of the classical standard of civilization in international society, 'a "civilized" state adheres to generally accepted international law, including the laws of war'. 5 By their very nature, barbarians and savages are deemed incapable of abiding by such laws. While terrorists might be capable, they are unwilling to do so. (Although al-Qa'ida and other radical jihadis have gone to considerable lengths to demonstrate that they are adhering to-many would argue distorted-Sharia law, Qur'anic principles and Islamic tradition in pursuing their cause. ${ }^{6}$ ) In this respect terrorists and terrorist organizations are something akin to modern-day savages; at least in terms of their (problematic) place in the international system and international law. Just what I mean by 'modern-day savages' will be outlined below, but it is not the pejorative term that is sloppily bandied about in much of the rhetoric that has accompanied the declarations of the war on terrorism.

\section{Civilization as Socio-politics}

In essence, the capacity for reasonably complex socio-political organization and self-government according to prevailing standards are widely thought of as central requirements of civilization. The presence, or otherwise, of the institutions of society that facilitate governance in accordance with established traditions-originally European but now more broadly Western-have long been regarded as the hallmark of the makings of, or potential for, civilization. Central to the ideal of civilization are its tripartite components as identified by R. G. Collingwood: economic civilization, social civilization and legal civilization. ${ }^{7}$ What they amount to is socio-political civilization, or the capacity of a collective to organize and govern itself under a system of laws or constitution. This issue has been explored in detail elsewhere and thus I do not want to spend too much time on it here. ${ }^{8}$ An exemplar

5 Gerrit W. Gong, The Standard of 'Civilization' in International Society (Oxford: Clarendon Press, 1984), pp. 14-15.

6 See Quintan Wiktorowicz and John Kaltner, 'Killing in the Name of Islam: Al-Qaeda's Justification for September 11', Middle East Policy, 10, 2 (2003), pp. 76-92; and Wiktorowicz, 'A Genealogy of Radical Islam', pp. 75-97.

7 R. G. Collingwood, 'Appendix 2: What "Civilization” Means', in David Boucher (ed.), The New Leviathan, (Oxford: Clarendon Press, 1992), pp. 502-511.

8 See Brett Bowden, 'The Ideal of Civilisation: Its Origins and Socio-Political Character', Critical Review of International Social and Political Philosophy, 7, 1 (2004), pp. 25-50. 
of the importance of society to the qualification of civilization is J. S Mill's recipe in which he lists the 'ingredients of civilization'. Following Montesquieu to some degree, Mill states that whereas

a savage tribe consists of a handful of individuals, wandering or thinly scattered over a vast tract of country: a dense population, therefore, dwelling in fixed habitations, and largely collected together in towns and villages, we term civilized. In savage life there is no commerce, no manufactures, no agriculture, or next to none; a country in the fruits of agriculture, commerce, and manufactures, we call civilized. In savage communities each person shifts for himself; except in war (and even then very imperfectly) we seldom see any joint operations carried on by the union of many; nor do savages find much pleasure in each other's society. Wherever, therefore, we find human beings acting together for common purposes in large bodies, and enjoying the pleasures of social intercourse, we term them civilized.'

Key to my purposes here and hinted at in Mill's recipe is that an important aspect of the organizational capability of civilized societies is a capacity for self-defence and an understanding of and willingness to adhere to the 'civilized' laws of war-making. As noted by the American anthropologist, Harry Holbert Turney-High, in his study Primitive War, the 'war complex fits with the rest of the pattern of social organization, which in turn seems to have a close correlation with victory in technological and economic configurations' ${ }^{10}$ A point made earlier by Adam Smith in the Wealth of Nations.

Of particular note here are the normative demands of the ideal of civilization. As the French linguist Jean Starobinski points out, 'as a value, civilization constitutes a political and moral norm. It is the criterion against which barbarity, or non-civilization, is judged and condemned. ${ }^{11}$ A similar sort of argument is made by Anthony Pagden, who states that civilization 'describes a state, social, political, cultural, aesthetic-even moral and physical — which is held to be the optimum condition for all [hu]mankind, and this involves the implicit claim that only the civilized can know what it is to be civilized'. ${ }^{12}$ The argument that only the civilized know what it means to be civilized is an important one; as Starobinski argues, the 'historical moment in which the word civilization appears marks the advent of self-reflection, the emergence of consciousness that thinks it understands the nature of its own activity'. More specifically, it marks 'the moment that Western civilization becomes aware of itself reflectively, it sees itself as one civilization among others. Having achieved self-consciousness, civilization immediately discovers civilizations. ${ }^{13}$ But, as Norbert Elias notes, it is not a case of Western civilization as just one among equals, for the very concept of civilization 'expresses the self-consciousness of the West ... It sums up everything in which Western society of the last two or three centuries believes itself superior to earlier societies or "more primitive" contemporary ones. ${ }^{14}$ Included in this sense of superiority are the art and ethics of war. Arising out of centuries of encounters with Others, ${ }^{15}$ Europe and the West have proclaimed a strategic and technological capability that remains unrivalled on the battlefield. At the same time Europeans-cum-Westerners have long laid claim to a monopoly on the moral high ground when it comes to questions of ius ad

9 John Stuart Mill, 'Civilization [1836]', in Gertrude Himmelfarb (ed.), Essays on Politics and Culture (Garden City, NY: Doubleday, 1962), p. 52.

10 Harry Holbert Turney-High, Primitive War; Its Practice and Concepts, 2nd edn (Columbia: University of South Carolina Press, 1971), p. 23.

11 Jean Starobinski, 'The Word Civilization', in Blessings in Disguise; or The Morality of Evil, trans. Arthur Goldhammer (Cambridge MA: Harvard University Press, 1993), p. 31.

12 Anthony Pagden, 'The "Defence of Civilization" in Eighteenth-Century Social Theory', History of the Human Sciences, 1, 1 (1988), p. 33.

13 Starobinski, 'Civilization', p. 32, italics in original.

14 Norbert Elias, The Civilizing Process, trans. Edmund Jephcott, rev. edn (Oxford: Blackwell, [1939] 2000), p. 5, italics in original.

15 See Edward W. Said, Orientalism (London: Routledge \& Kegan Paul, 1978). 
bellum (just causes of war) and ius in bello (laws governing conduct of war). Although this is not to suppose that other parties to a conflict do not hold similar views of their own. ${ }^{16}$

The oft-overlooked implications of this value-laden conception of civilization led to what Georg Schwarzenberger called the 'standard of civilization in international law'; or what Gong later termed the 'standard of civilization in international society'. ${ }^{17}$ Historically, the standard of civilization was a means used in international law to distinguish between civilized and uncivilized peoples in order to determine membership in the international society of states. The concept entered international legal texts and practice in the 18th and 19th centuries under the influence of anthropologists and ethnologists who drew distinctions between civilized, barbarian and savage peoples based on their respective capacities for social cooperation and organization. Operating primarily during the European colonial period, the standard of civilization was a legal mechanism designed to set the benchmark for the ascent of non-European states to the ranks of the civilized 'Family of Nations', and, with this, their full recognition under international law. A civilized state required: (a) basic institutions of government and public bureaucracy; (b) organizational capacity for selfdefence; (c) a published legal code and adherence to the rule of law; (d) the capacity to honour contracts in commerce and capital exchange; and (e) recognition of international law and norms, including the laws of war. ${ }^{18}$ If a nation could meet these requirements it was generally deemed to be a legitimate sovereign state entitled to full recognition as an international personality.

The inability of many non-European societies to meet these European-established criteria and the concomitant legal distinction that separated them from civilized societies led to the unequal treaty system of capitulations. The right of extraterritoriality, as it was also known, regulated relations between sovereign civilized states and quasi-sovereign uncivilized states in regard to their respective rights over, and obligations to, the citizens of civilized states living and operating in countries where capitulations were in force. In much of the uncivilized world this system of capitulations incrementally escalated to the point that it became the large-scale European civilizing missions that in turn became colonialism. As noted, one of the key criteria in determining a people's or society's approximation to civilization was their conduct in war; a topic that will now be explored in some detail below.

\section{Savage War}

The 'military horizon' was a figurative line drawn in the sand to distinguish 'civilized' European warfare, which was supposedly organized, constrained and chivalrous, from the chaotic nature of the undisciplined and opportunistic 'primitive' warfare practised by savages and barbarians. As Turney-High put it, the 'military horizon depends ... not upon the adequacy of weapons but the adequacy of team work, organization, and command'. Because of a perceived lack of organization and cooperation, and 'despite their face-painting

16 On this topic generally, see Michael Walzer, Just and Unjust Wars, 3rd edn (New York: Basic Books, [1977] 2000). See also John Kelsay and James Turner Johnson (eds), Just War and Jihad: Historical and Theoretical Perspectives on War and Peace in Western and Islamic Traditions (New York: Greenwood Press, 1991); and James Turner Johnson, The Holy War Idea in Western and Islamic Traditions (University Park: Pennsylvania State University Press, 1997).

17 Georg Schwarzenberger, 'The Standard of Civilisation in International Law', in George W. Keeton and Georg Schwarzenberger (eds), Current Legal Problems, (London: Stevens, 1955), pp. 212-234; Gong, Standard of 'Civilization' in International Society.

18 See Gong, Standard of 'Civilization' in International Society, pp. 14-15; and Brett Bowden, 'In the Name of Progress and Peace: The "Standard of Civilization" and the Universalizing Project', Alternatives, 29, 1 (2004), pp. 43-68. 
and sporadic butchery', uncivilized peoples are thought to fall short of the military horizon. Thus they are 'not soldiers' and nor do they 'contain the rudiments of the arts of war'. ${ }^{19}$

Characterizations such as these draw on work like that of José de Acosta's Natural and Moral History of the Indies. Based on his late-16th-century study of the indigenous peoples of the New World, Acosta's observations led him to write, 'it must be pointed out that three kinds of government and styles of life have been found among the Indians'. Of these, 'the chief kind, and the best, has been the realm or monarchy, as was that of the Incas and of Moctezuma'. The second system of social organization he describes as 'free associations or communities, where the people are governed by the advice of many, and are like councils. In time of war these elect a captain who is obeyed by a whole tribe or province.' Acosta's description of the third arrangement is reminiscent of Aristotle's reference in The Politics to the reviled character in Homer: 'The third kind of government', declares Acosta, 'is absolutely barbarous, and these are Indians who have neither laws nor king nor fixed dwellings but go in herds like wild animals and savages. 20

The various and varied first-hand accounts emanating from the frontiers of the Americas to Europe carried great influence, and are discernable in such celebrated texts as William Robertson's History of America, in which he wrote,

When polished nations have obtained the glory of victory, or have acquired an addition of territory, they may terminate a war with honor. But savages are not satisfied until they extirpate the community which is the object of their hatred. They fight not to conquer, but to destroy ... If they engage in hostilities, it is with a resolution to never to see the face of the enemy in peace, but to prosecute the quarrel with immortal enmity ... With respect to their enemies, the rage of vengeance knows no bounds. When under the dominion of this passion, man becomes the most cruel of all animals. He neither pities, nor forgives, nor spares ... They place not their glory in attacking their enemies with open force. To surprise and destroy is the greatest merit of a commander, and the highest pride of his followers. ${ }^{21}$

The casting of the warfare of the Amerindians as savage when compared with that of Europeans or settlers-however inappropriate, misguided or downright inaccurate the comparison-even made its way into such monumental documents as the United States of America's Declaration of Independence, 4 July 1776. In the Declaration Thomas Jefferson charges that the British King 'has excited domestic insurrections among us, and has endeavored to bring on the inhabitants of our frontiers, the merciless Indian savages, whose known rule of warfare is an undistinguished destruction of all ages, sexes, and conditions'. The Declaration is revered to this day, despite such tasteless characterizations and aspersions.

While the discovery of such 'exotic creatures' as the Indians of the New World might have come as something of a surprise, the subsequent confrontation and incongruity between the ways of the Old World and those of the New were not altogether unexpected. As the 18th-century jurist Robert Ward, who would later serve in the British House of Commons and in executive posts, noted, 'When the New World was opened to the spirit and adventure of the Old, it was reasonable to expect what was found; new laws and customs, as well as a new people and language. ${ }^{22}$ The characterization of the Amerindians as inferior, almost sub-human beings was also not a new development; beyond the borders of Europe and the fledgling European settler colonies, much of the non-European world

19 Turney-High, Primitive War, p. 23.

20 José de Acosta, Natural and Moral History of the Indies, ed. Jane E. Mangan, trans. Frances M. López-Morillas (Durham. NC/London: Duke University Press, [1590] 2002), p. 359.

21 William Robertson, The History of America, 12th edn (London: Cadell \& Davies, 1812), Vol. 2, pp. 149-154.

22 Robert Ward, An Enquiry into the Foundation and History of the Law of Nations in Europe from the Time of the Greeks and Romans to the Age of Grotius, 2 vols (New York/London: Garland, [1795] 1973), Vol. 1, p. 36. 
was widely thought to consist of uncivilized "nations that are still approaching to a state of nature'. ${ }^{23}$ The Amerindians were merely deemed to be far less civilized than any peoples previously encountered (as were other indigenous peoples 'discovered' in later centuries, such as the Australian Aborigines and the Maori in Aoteroa/New Zealand). Expressing sentiments that were held by the majority of his predecessors, contemporaries and immediate successors alike, Ward claimed,

If we look to the Mahometan [sic] and Turkish nations ... their ignorance and barbarity repels all examination, and if they have received any improvement since the days when they first set foot in Europe, it is probably from their connection with people professing the very religion which they most hate and despise. The same inferiority in this sort of conduct, is to be found even among the Chinese, so famed for eminence in every other branch of knowledge, and in the science of morals itself. Their wars have always been carried on with Eastern barbarity, and their known laws against strangers would alone demonstrate the point. ${ }^{24}$

Again, one of the key criteria of civilization, as Mill put it, is that savages, barbarians and slaves are 'incapable of acting in concert'. And nowhere is the capacity for cooperation more important than in the theatre of war; Mill continues, 'Look even at war, the most serious business of a barbarous people; see what a figure rude nations, or semi-civilized and enslaved nations, have made against civilized ones, from Marathon downwards. Why? Because discipline is more powerful than numbers, and discipline, that is, perfect co-operation, is an attribute of civilization.' And nowhere was this more obvious to Mill than in looking to his 'own times ... see how incapable half-savages are of co-operation'. ${ }^{25}$

\section{War on 'Savages'}

The idea that organized, well governed, civilized peoples - such as those of Europe-generally have an advantage over less organized, ungovernable, uncivilized peoples-as most nonEuropeans were characterized-has a long history when it comes to matters of conquest. Georg W. F. Hegel suggests that 'it arises above all in the Iliad where the Greeks take the field against the Asiatics and thereby fight the first epic battles in the tremendous opposition that led to the wars which constitute in Greek history a turning-point in world-history'. Hegel continues,

In a similar way the Cid fights against the Moors; in Tasso and Ariosto the Christians fight against the Saracens, in Camoens the Portuguese against the Indians. And so in almost all the great epics we see peoples different in Morals, religion, speech, in short in mind and surroundings, arrayed against one another; and we are made completely at peace by the world-historically justified victory of the higher principle over the lower which succumbs to a bravery that leaves nothing over the defeated. ${ }^{26}$

The conclusion Hegel draws from this is that, 'In this sense, the epics of the past describe the triumph of the West over the East, [the triumph] of European moderation, and the individual beauty of a reason that sets limits to itself. ${ }^{27}$ Furthermore, as he writes elsewhere, the 'inner dialectic' of a civilized society drives it 'to push beyond its own limits and seek markets' in territories that are 'generally backward in industry', in turn generating the 'colonizing

23 Ibid., Vol. 2, p. 2.

24 Ibid., pp. 3-4, italics in original.

25 Mill, 'Civilization', p. 55.

26 G. W. F. Hegel, Aesthetics: Lectures on Fine Art, trans. T. M. Knox, 2 vols (Oxford: Clarendon Press, 1975), Vol. 2, pp. 1061-1062.

27 Ibid., p. 1062. 
activity ... to which the mature civil society is driven' ${ }^{28}$ The conquest of native peoples therefore-whether they be the Amerindians in the Americas, the Aborigines of Australia, the Maori in New Zealand or the various peoples of Africa-is seen as a largely natural and inevitable series of events that conform to recent patterns in world history.

It was not always the case that the supposedly more civilized triumphed over the less civilized; Adam Smith argued that in 'ancient times the opulent and civilized found it difficult to defend themselves against the poor and barbarous nations' (the victory of the barbarian hordes of Germany over the armies of imperial Rome being an example). But, as he further noted, with the coming of industrialization and commercial society the tables were quickly turned, for 'In modern times the poor and barbarous nations find it difficult to defend themselves against the opulent and civilized'. The reason Smith gives for this reverse in fortunes is that in 'modern war the great expense of firearms gives an evident advantage to the nation which can best afford the expense, and consequently to an opulent and civilized over a poor and barbarous nation'. Smith's observations on the asymmetrical nature of warfare highlight and reiterate the lopsided and almost inevitably violent nature of the European exportation and imposition of 'civilization' to the farthest reaches of the globe. And, just in case there are any doubts, Smith concludes that the 'invention of firearms, an invention which at first sight appears to be so pernicious, is certainly favorable both to the permanency and to the extension of civilization'. ${ }^{29}$

One of the critical questions arising out of the 'savage war' thesis is one that was posed by the American jurist Quincy Wright in the wake of the French bombardment of Damascus in October 1925 (Syria being a French mandate at the time). Wright asked, 'Does international law require the application of laws of war to people of a different civilization?' To which he immediately replied,

The ancient Israelites are said to have denied the usual war restrictions to certain tribes against
which they were sworn enemies, the ancient Greeks considered the rules of war recognized
among Hellenes inapplicable to barbarians, and medieval Christian civilization took a similar
attitude toward war with the infidel. An English writer [F. W. Hirst, The Arbiter in Council,
p. 230] in 1906 draws attention to 'the peculiarly barbarous type of warfare which civilized
Powers wage against tribes of inferior civilization. When I contemplate,' he adds, 'such
modern heroes as Gordon, and Kitchener, and Roberts, I find them in affiance with slave
dealers or Mandarins, or cutting down fruit trees, burning farms, concentrating women and chil-
dren, protecting military trains with prisoners, bribing other prisoners to fight against their fellow
countrymen. These are performances which seem to take us back to the bad old times. What a
terrible tale will the recording angel have to note against England and Germany in South
Africa, against France in Madagascar and Tonquin, against the United States in the Philippines,
against Spain in Cuba, against the Dutch in the East Indies, against the Belgians in the Congo
State.' Possibly the emphasis, in most accounts of the recent bombardment of Damascus, upon
the fact that relatively slight damage was done to Europeans and Americans indicates the exist-
ence of this distinction in the moral sense of western communities.

Wright's rueful lament of French heavy-handedness in Syria-which he equates to 'a policy of terrorism, ${ }^{31}$ - is something of an exception to the rule when it comes to self-assessments of the West's conduct in its dealing with other civilizations. In response to Wright's assessment of the legality of the French bombing of Damascus - and the broader moral interpitude of which it is symptomatic_Eldridge Colby, a captain in the United States Army, replies,

28 G. W. F. Hegel, Philosophy of Right, trans. T. M. Knox (Oxford: Clarendon Press, [1821] 1958), paras 246-248, p. 151.

29 All quotes from: Adam Smith, The Wealth of Nations, 2 vols (London: J. M. Dent [1776] 1910), Vol. 2, p. 198.

30 Quincy Wright, 'The Bombardment of Damascus', American Journal of International Law, 20, 2 (1926), p. 266.

31 Ibid., p. 273. 
'however Professor Wright may deplore the fact-[there is] one matter which must be faced. The distinction is existent.' Colby continues,

It is based on a difference in methods of waging war and on different doctrines of decency in war. When combatants and non-combatants are practically identical among a people, and savage or semi-savage peoples take advantage of this identity to effect ruses, surprises, and massacres on the 'regular' enemies, commanders must attack their problems in entirely different ways from those in which they proceed against Western peoples. When a war is between 'regular' troops and what are termed 'irregular' troops the mind must approach differently all matters of strategy and tactics, and, necessarily also, matters of rules of war. ${ }^{32}$

In support of his argument Colby draws on a range of judicial and military authorities to demonstrate that things could not be any other way. ${ }^{33}$ In The Reformation of War, Colonel J. F. C. Fuller of the British Army writes, 'In small wars against uncivilized nations, the form of warfare to be adopted must tone with the shade of culture existing in the land, by which I mean that, against peoples possessing a low civilization, war must be more brutal in type. ${ }^{34}$ The British Manual of Military Law states that 'the rules of International Law apply only to warfare between civilized nations, where both parties understand them and are prepared to carry them out. They do not apply in wars with uncivilized States and tribes. ${ }^{35}$ Colby further argues that the 'long list of Indian wars in which the troopers of the United States have defended and pushed westwards the frontiers of America bear eloquent testimony to the unified tribal action in war [men, women and child combatants], and to the almost universal brutality of the red-skinned fighter'. ${ }^{36}$ While he acknowledges it is 'good to be decent', it is 'good to use proper discretion' and it is 'good to observe the decencies of international law', he insists that 'it is a fact that against uncivilized people who do not know international law and do not observe it, and would take advantage of one who did, there must be something else'. ${ }^{37}$ Setting aside the dubious point being made here, just one of the obvious problems with this line of argument is: how can one knowingly take advantage of something they do not know exists? And does this give the other party the right to turn their back on a set of laws they claim to abide by and that are held up as a marker of their civilization. Colby concludes that the 'real essence of the matter is that devastation and annihilation is the principal method of warfare that savage tribes know'. ${ }^{38}$ As such, 'civilized' Westerners are somehow supposed to be justified in adopting 'more brutal' methods as they go about devastating and annihilating the 'uncivilized' hordes.

\section{'Savages' on War}

There is, of course, another side to this tale of savage war; a side that cannot be told in full, in large part because rarely are the vanquished allowed the opportunity to tell their tale of woe. As Arnold Toynbee poignantly notes in his masterwork, A Study of History, 'We have to remember that the annals of this warfare between "civilization" and "barbarism" have

32 Eldridge Colby, 'How to Fight Savage Tribes', American Journal of International Law, 21, 2 (1927), p. 279.

33 On the ambiguous position of 'uncivilized' peoples in international law-partially subjected to it, but afforded minimal protection under it-see Brett Bowden, 'The Colonial Origins of International Law: European Expansion and the Classical Standard of Civilisation', Journal of the History of International Law/Revue d'histoire du droit international, 7, 1 (2005), pp. 1-23.

34 Colby, 'Savage Tribes', p. 280; and J. F. C. Fuller, The Reformation of War (London: Hutchinson, 1923), p. 191.

35 Colby, 'Savage Tribes', p. 280; and Great Britain War Office, Manual of Military Law (London: HMSO, 1914), p. 235.

36 Colby, 'Savage Tribes', p. 284.

37 Ibid., p. 287.

38 Ibid., p. 285. 
been written almost exclusively by the scribes of the "civilized" camp. ${ }^{39}$ Sadly, it has often been the case that there is no one left to tell the other side of the story, and often when there is it is discounted because of the assumed unreliability of the oral history of 'savages'. Thus, despite being on the receiving end of most of history's 'devastation and annihilation', it is savages and their mode of warfare that are deemed reprehensible or ghastly by civilized standards. Needless to say there are in fact countless untold or unacknowledged other sides of the story as experienced by the various peoples who have been designated as savages and barbarians. Of those that do exist I will draw on extracts of only a few accounts here to demonstrate a point that is counterintuitive to the assessments and declarations recounted above, and allow readers to extrapolate for themselves what they will.

Dee Brown's catalogue of injustices against Amerindians in Bury My Heart at Wounded Knee recalls the following early encounter with Europeans:

When the Dutch came to Manhattan Island, Peter Minuit purchased it for sixty guilders in fishhooks and glass beads, but encouraged the Indians to remain and continue exchanging their valuable peltries for such trinkets. In 1641, Willem Kieft levied tribute upon the Mahicans and sent soldiers to Staten Island to punish the Raritans for offenses which had been committed not by them but by white settlers. The Raritans resisted arrest, and the soldiers killed four of them. When the Indians retaliated by killing four Dutchmen, Kieft ordered the massacre of two entire villages while the inhabitants slept. The Dutch soldiers ran their bayonets through men, women, and children, hacked their bodies to pieces, and then leveled the villages with fire. ${ }^{40}$

Speaking of what might be described as the other bookend of the war against the Indians of America, Black Elk reflected thus on the massacre of Sioux peoples at the hands of American soldiers in late December 1890 at Wounded Knee:

I did not know then how much was ended. When I look back now from this high hill of my old age, I can still see the butchered women and children lying heaped and scattered all along the crooked gulch as plain as when I saw them with eyes still young. And I can see that something else died there in the bloody mud, and was buried in the blizzard. A people's dream died there. It was a beautiful dream. ${ }^{41}$

Chief Joseph (Hin-mah-too-yah-lat-kekht) of the Nez Percés of the Wallowa Valley in modernday Oregon reflected on his people's plight at being forced from their homeland as the frontier pushed west: 'I knew we were too weak to fight the United States. ${ }^{42}$ In contradistinction to the many arguments listed above, he stressed that 'When an Indian fights, he only shoots to kill; but soldiers shoot at random'. He continued, 'We do not believe in scalping, nor in killing wounded men. Soldiers do not kill many Indians unless they are wounded and left upon the battlefield. Then they kill Indians. ${ }^{43}$ His recollections demonstrate how Native Americans could also be skilful fighters against the odds: 'General Howard ... attacked us with three hundred and fifty soldiers and settlers. We had two hundred and fifty warriors. The fight lasted twentyseven hours. We lost four killed and several wounded. General Howard's losses were twenty-five men killed and sixty wounded. ${ }^{44}$ Joseph continues,

In the fight with General Gibbon we lost fifty women and children and thirty fighting men. We remained long enough to bury our dead. The Nez Percés never make war on women and children;

39 Arnold J. Toynbee, A Study of History, abridged D. C. Somervell, 2 vols (Oxford: Oxford University Press, 1947), Vol. 1, p. 420.

40 Dee Brown, Bury My Heart at Wounded Knee (New York, Chicago, and San Francisco: Holt, Rinehart \& Winston, 1970), p. 4.

41 Black Elk, Black Elk Speaks: Being the Life Story of a Holy Man of the Oglala Sioux, as told through John G. Neihardt (Flaming Rainbow) (Lincoln: University of Nebraska Press, 1988), p. 270.

42 Young Joseph, 'An Indian's View of Indian Affairs', North American Review, 269, April 1879, p. 424.

43 Ibid., p. 425.

44 Ibid., p. 426. 
we could have killed a great many women and children while the war lasted, but we would feel ashamed to do so cowardly an act ... On the way we captured one white man and two white women. We released them at the end of three days. They were treated kindly. The women were not insulted. Can the white soldiers tell me of one time when Indian women were taken prisoners, and held three days and then released without being insulted? Were the Nez Percés women who fell into the hands of General Howard's soldiers treated with such respect? I deny that a Nez Percé was ever guilty of such a crime. ${ }^{45}$

Chief Joseph further recalled, 'We could have escaped from Bear Paw Mountain if we had left our wounded, old women, and children behind. We were unwilling to do this. We had never heard of a wounded Indian recovering while in the hands of white men. ${ }^{46}$ These are just a few accounts drawn from one frontier in the often violent coming together of 'civilization' and 'savagery'; they are powerful testimonies that in many ways speak for themselves.

\section{Terrorism and the New Savagery}

Even prior to September 11, 2001, terrorism was regarded as some form of 'new barbarism' or contemporary 'savage war'. The military historian and theorist Everett Wheeler comments that the 'shock of modern terrorism resembles the outrage of seventeenth- or eighteenthcentury European regulars in North America when ambushed by Indians who ignored the European rules of the game'. ${ }^{47}$ (Another who is unwilling to acknowledge or fails to recognize that it is impossible to ignore rules that one does not know exist.) Terrorism is denounced for 'the shock value of unexpected savagery toward innocent victims [which] creates the impression of civilization teetering on the brink of anarchy', ${ }^{48}$ and the terrorist is one who 'shuck[s] off in particularly violent and blatant fashion the restraints that divide civil society from the state of nature', ${ }^{49}$ with the aim of announcing that the 'whole world is a Hobbesian state of nature' devoid of civil order. ${ }^{50}$

In the tradition of the 'savage war' thesis, Wheeler contends that 'conventional warfare requires, above all, open battle and observance of rules, although many remain unwritten', while 'terrorism like primitive warfare is unconventional in its most literal sense: the parties in conflict lack a shared set of values'. Like the warfare attributed to the savages and barbarians of the Americas, Australasia, Africa, Asia, the Middle East and even Eurasia, 'above all, terrorists avoid pitched battle and confrontation with regular armed forces, relying on the tactics of primitive warfare-surprise, ambush, deception, and hit-and-run maneuvers' ${ }^{51}$ This slide away from conventional modes of warfare that are supposedly noble and chivalrous is all part and parcel of what John Keane views as a 'murderous reductio ad absurdum' in which today's terrorists and guerrillas are akin to 'autistic'. They are further described as 'self-destructive gangsters' who 'vandalize the threefold division of government, army and civilians once enforced by conventional warfare and the Westphalian and Philadelphian models'. Thus they 'ransack the legal monopoly of armed force long claimed by states; they put an end to

45 Ibid., p. 427.

46 Ibid., p. 429.

47 Everett L. Wheeler, 'Terrorism and Military Theory: An Historical Perspective', Terrorism and Political Violence, 3, 1 (1991), p. 15.

48 Ibid., p. 6.

49 Loren E. Lomasky, 'The Political Significance of Terrorism', in R. G. Frey and C. W. Morris (eds), Violence, Terrorism, and Justice (Cambridge, England: Cambridge University Press, 1991), p. 99.

50 Robert Phillips, 'Terrorism: Historical Roots and Moral Justifications', in M. Warner and R. Crisp (eds), Terrorism, Protest and Power (Aldershot, England: Edward Elgar, 1990), p. 77.

51 Wheeler, 'Terrorism', pp. 14-15. 
the distinction between war and crime; ensuring that conflict degenerates into "criminal anarchy", into deathly destruction and self-destruction'. ${ }^{2}$

In speaking of this civilized-savage divide, Wheeler argues that the Western tradition of warfare displays some 'tension between rival norms', or what he terms the 'Achilles ethos, advocating chivalry, pitched battle and open, direct means, and the Odysseus ethos, favoring trickery, deceit, indirect means and avoidance of pitched battle'; with terrorism cast as 'Odysseus gone mad'. ${ }^{53}$ But the blanket aerial bombing of Dresden and the dropping of atomic bombs on Hiroshima and Nagasaki, to take just two examples-which include the targeting of civilians-would indicate that this tension is very close to the surface. Or more accurately, such actions further expose and undermine the much cherished myth of Western chivalry. It also relies on the problematic exclusion of Europe's fascists and Nazis from the Western camp. If there is a tension in the Western mindset when it comes to choosing between rival norms of warfare, the nature of the combatants arrayed against the West is a key determining factor.

In the immediate aftermath of the September 11, 2001 terrorist attacks the distinguished British military historian Sir John Keegan wrote an opinion piece for Daily Telegraph (reprinted in newspapers around the world) in which he proclaimed,

Westerners fight face to face, in stand-up battle, and go on until one side or the other gives in. They choose the crudest of weapons available, but observe what to non-Westerners may well seem curious rules of honor. Orientals, by contrast, shrink from pitched battle, which they often deride as a sort of game, preferring ambush, surprise, treachery and deceit as the best way to overcome an enemy. ${ }^{54}$

In the same article Keegan claims that 'Relentless as opposed to surprise and sensation is the Western way of warfare'. It is said to be a style of war-making that is 'deeply injurious to the Oriental style and rhetoric of war making'. Keegan goes on to outline what he believes to be the obvious link between the savages of the past and the savages of the present, declaring that 'Oriental war-makers, today terrorists, expect ambushes and raids to destabilize their opponents, allowing them to win further victories by horrifying outrages at a later stage'. Speaking of the al-Qa'ida terrorist network elsewhere, Keegan suggests that it is 'very ... it's very Islamic, but particularly very Arab-and you can see that it has its roots in Islamic but particularly Arab Islamic style of war-making that goes back to the seventh century AD. The surprise attack ... victory ... killing for its own sake' ${ }^{55}$ Despite the benefit of greater knowledge and understanding of other civilizations, these sentiments are not too dissimilar from those put forward by chroniclers of the New World and other 'savage lands' based on mere speculation, invention and the unreliable accounts of travellers.

Leaders of the Western world allied against al-Qa'ida and its hosts have been at pains to emphasize that the war on terrorism is not a war against the Islamic or Arab worlds; it is not, they stress, a 'clash of civilizations', as made famous by Samuel Huntington. ${ }^{56}$ Likewise, most have gone to lengths-Italian Prime Minister Silvio Berlusconi being a notable exception ${ }^{57}$ - to ensure that they do not portray Islamic or Arabic civilization as inferior to

52 John Keane, Reflections on Violence (London: Verso, 1996), p. 141.

53 Wheeler, 'Terrorism', pp. 24, 27.

54 John Keegan, 'Why the West Will Win', The Age (Melbourne), 9 October 2001, p. 19.

55 John Keegan, interviewed on Foreign Correspondent, Australian Broadcasting Corporation, 10 October 2001, <http://www.abc.net.au/foreign/stories/s387060.htm> (accessed 12 September 2006).

56 See Samuel P. Huntington, 'The Clash of Civilizations?', Foreign Affairs, 72, 3 (1993), pp. 22-49; and The Clash of Civilizations and the Remaking of World Order (London: Touchstone Books, 1998).

57 While in Berlin on 26 September, 2001, Berlusconi stated, "We should be conscious of the superiority of our civilization, which consists of a value system that has given people widespread prosperity in those countries that embrace it and guarantees respect for human rights and religion. This respect certainly does not exist in Islamic countries.' Following the uproar caused by his remarks Berlusconi later retracted them and claimed he had been misquoted and taken out of context. The damage had been done. 
Western civilization. This, however, does not mean that commentators in the West have felt obliged to follow suit. For instance, Keegan concluded his observations on the war on terrorism with the following ill-considered diatribe that recalls ignorant observations of centuries past.

This war belongs within the much larger spectrum of a far older conflict between settled, creative, productive Westerners and predatory, destructive Orientals. It is no good pretending that the peoples of the desert and the empty spaces exist on the same level of civilization as those who farm and manufacture. They do not. Their attitude to the West has always been that it is a world ripe for the picking. When the West turned nasty, and fought back, with better weapons and superior tactics and strategy, the East did not seek to emulate it but to express its anger in new forms of the raid and surprise attack. ${ }^{58}$

I will return to the specifics of the savage-war thesis momentarily, but first I want to further explore my other key concern here: the not altogether unrelated notion that the war on terrorism is a war like no other. When political and military leaders struggle to demonstrate the progress they claim is being made in the 'war on terror' and that 'we are winning the war', more often than not they resort to the tired but trusted explanation, 'It is a war like no other.' In one sense they are right; it is a war like no other. But every war is a war like no other. At the same time, in a strange way every war is like every other war (in some respects at least). It should be evident from some of the examples and arguments set out above that in the fighting of the war on terror there are some precedents and parallels in the characterization of combatants from conflicts past. An equally important question here is: Is the war on terrorism really a war at all?

If we follow the widely acknowledged criteria as set out by Jean-Jacques Rousseau in the Social Contract, then it is probably not a true war. Rousseau wrote, 'War . . is not a relation between men, but between states; in war individuals are enemies wholly by chance, not as men, not even as citizens, but only as soldiers; not as members of their country, but only as its defenders. In a word, a state can have as an enemy only another state, not men, because there can be no real relation between things possessing different intrinsic natures. ${ }^{59}$ But Rousseau's declaration seems a bit dated in a time of an open-ended war on terrorism in which one of the protagonists is not a state. Despite appearances and the various claims and counter-claims being made this is far from a clear-cut issue; there is more grey than black and white. The war on terror is being fought on the ground; it is being fought in Afghanistan, but no longer against Afghanistan. It is being fought in Iraq, but not necessarily against Iraq (if there is still such a country or nation). And from time to time it is being fought in London, and Madrid, and Bali, and wherever else the terrorists choose to turn into a battlefield.

According to Wheeler terrorism should be recognized as a form of warfare, albeit a primitive form of warfare with links and close connections to guerrilla modes of war. He notes that from the point of view 'of traditional military theory ... terrorism forms a subset of the ideas included within the concept of stratagem'. 60 'Stratagem' is in turn defined 'as either a strategic or a tactical act of trickery, deceit, or cunning in war whereby one attempts to gain psychological or material advantage over an opponent'. ${ }^{61}$ The question of whether terrorism and the concomitant 'war on terror' are truly a war is an important one that goes right to the heart of the legal status of the combatants and the obligations imposed upon them. As

58 Keegan, 'Why the West Will Win'. For a more favourable and balanced comparative study, see Roxanne L. Euben, Enemy in the Mirror: Islamic Fundamentalism and the Limits of Modern Rationalism: A Work of Comparative Political Theory (Princeton, NJ: Priceton University Press, 1999).

59 Jean-Jacques Rousseau, The Social Contract (Harmondsworth, England: Penguin, [1762] 1968), p. 56.

60 Wheeler, 'Terrorism', p. 10.

61 Ibid., p. 24. 
Wheeler notes, the "problem of legal status is relevant to the connection of guerrilla warfare and terrorism with primitive warfare. In the Graeco-Roman world a soldier was a legally defined enemy (iustus hostis) as opposed to pirates and outlaws, whose violence was criminal and who lay without claim to any legal status or rights. ${ }^{62}$ This legal neverland is the very position that those adjudged 'enemy combatants' find themselves in, first at Camp X-Ray and then at Camp Delta in Guantanamo Bay, Cuba; devoid of the legal rights and privileges afforded prisoners of war.

\section{The War on Terror and the Terror of War}

In an 'Address to the Nation' from Fort Bragg in North Carolina on 28 June 2005, George W. Bush further underlined the notion that tactics employed by parties to a conflict reflect their degree of civility: the civilized supposedly chivalrous and noble; the uncivilized barbarous and cowardly. Bush declared,

We see the nature of the enemy in terrorists who exploded car bombs along a busy shopping street in Baghdad, including one outside a mosque. We see the nature of the enemy in terrorists who sent a suicide bomber to a teaching hospital in Mosul. We see the nature of the enemy in terrorists who behead civilian hostages and broadcast their atrocities for the world to see. These are savage acts of violence.

Bush went on to state that 'We're fighting against men with blind hatred-and armed with lethal weapons-who are capable of any atrocity'. These modern savages, like the Amerindians and the Viet Cong before them, 'wear no uniform; they respect no laws of warfare or morality'. ${ }^{63}$ When combined with the mantra that the war on terror is a 'war like no other' against an enemy that is 'pure evil' and refuses to 'fight by the rules', the inference is that this war demands tactics and means of warfare that are necessarily more brutal than might otherwise be employed. ${ }^{64}$

Terrorists have indeed committed atrocious and criminal acts. As have those fighting the war on terrorism. For the former, atrocities and acts of callousness are prescribed policy, despite bin Laden's declaration:

We are carrying on the mission of our Prophet, Muhammad (peace be upon him). The mission is to spread the word of God, not to indulge [in] massacring people. We ourselves are the target of killings, destruction and atrocities. We are only defending ourselves. This is defensive Jihad. We want to defend our people and our land. That is why I say that if we don't get security, the Americans, too would not get security. This is a simple formula that even an American child can understand. This is the formula of live and let live. ${ }^{65}$

But al-Qa'ida has also gone to great lengths to rationalize and justify the targeting of civilians, the use of suicide bombers, and the killing of fellow Muslims. ${ }^{66}$ Those fighting the war on terror also try to justify or explain away atrocities as isolated incidents committed by a handful of rogue troops; such as the shameful events at Abu Ghraib prison in Iraq.

62 Ibid., p. 18.

63 George W. Bush, 'President Addresses Nation, Discusses Iraq, War on Terror', 28 June 2005, <http://www. whitehouse.gov/news/releases/2005/06/20050628-7.html> (accessed 12 September 2006).

64 For a good account of the persistent feature in American politics of the 'inflation, stigmatization, and dehumanization of political foes', from 'the Indian cannibal ... [to] the agents of international terrorism', see Michael Paul Rogin, Ronald Reagan, the Movie: and Other Episodes in Political Demonology (Berkeley: University of California Press, 1987).

65 Osama bin Laden, interview with Hamid Mir, 'Osama Claims He Has Nukes: If US Uses N-Arms It Will Get Same Response', Dawn, 10 November 2001, <http://www.dawn.com/2001/11/10/top1.htm> (accessed 12 September 2006). Many of bin Laden's speechs are collected in Bruce Lawrence (ed.), Messages to the World: The Statements of Osama bin Laden, trans. James Howarth (London: Verso, 2005).

66 See Wiktorowicz, ‘A Genealogy of Radical Islam', pp. 75-97. 
But they still happened and continue to happen. There have also been many other unsavoury incidents and instances, such as widespread 'collateral damage'; enough to suggest that there is something more going on than isolated incidences of brutality. The point to be made here is that just because one side, the terrorists, choose to abandon the accepted rules of fair play, that does not mean that the other party to the conflict has to follow suit and adopt 'more brutal' and indiscriminate means of warfare.

It seems to me that what is really going on here is that in response to atrocities or acts of savagery by an uncivilized foe-September 11 and then Madrid and Bali and London, and then Bali again and on the ground in Iraq every day-the West, in the name of Civilization and the battle of good over evil, is seeking to justify a turn to any means necessary, including 'more brutal' means of warfare. A war against such an evil and unscrupulous barbarous enemy cannot be won by conventional means; rather 'we' must fight fire with fire-so the argument goes. Or at least this is what we try to convince ourselves. But perhaps it is more the case that those more base instincts and 'uncivilized' means are universal in appeal and have been at our disposal and employed by us - the West—all along. History seems to suggest as much. All too regularly we dehumanize our enemy-the uncivilized savage who lacks virtue, chivalry, is beyond the pale materially and morally-in order to justify to ourselves the recourse to the 'more brutal' means we claim to abhor and claim to be antithetical to our very ideal of Civilization. The dichotomy between the civilized, uniformed chivalrous combatant and the opportunistic, treacherous savage is a false one. Perhaps there is something in the argument that all people, fundamentally 'good' people included, are capable of doing bad or evil acts given certain circumstances. Just as 'bad' people are capable of random acts of kindness.

As Immanuel Kant reminded us in Perpetual Peace, 'even some philosophers have praised it [war] as an ennoblement of humanity, forgetting the pronouncement of the Greek who said, "War is an evil inasmuch as it produces more wicked men than it takes away." 67 We would also do well to take note of Walter Benjamin's poignantly made point that 'There is no document of civilization which is not at the same time a document of barbarism'. ${ }^{68}$ Nowhere is this more the case than in the crucible of war. And, as with every other war that has been or will ever be fought, no belligerent has a monopoly on the savagery and terror of war. The war on terror is no exception.

67 Immanuel Kant, 'Perpetual Peace: First Supplement', in Lewis White Beck (ed.), Kant On History (Indianapolis: Bobbs-Merrill, 1963), p. 111.

68 Walter Benjamin, Illuminations, ed. Hannah Arendt (New York: Schocken Books, 1969), p. 256. 